\title{
Serum antibody response in patients with mild Typhoid fever from southern Vietnam
}

\author{
D.L. House 1,2 , H. Vinh ${ }^{3}$, N.T. Chinh ${ }^{4}$, J.R. Wain ${ }^{1}$, C.M. Parry ${ }^{1}$, N.T. Quyen ${ }^{1}$, T.S. Diep ${ }^{3}$, T.T. Hien ${ }^{3}$, \\ J.J. Farrar ${ }^{1}$, N.J. White ${ }^{1}$, G. Dougan ${ }^{2}$
}

\begin{abstract}
Abstrak
Penelitian ini bertujuan untuk melihat tanggap kebal terhadap antigen LPS, flagelin dan Vi Salmonella typhi (S. typhi) pada pasien-pasien demam tifoid ringan di daerah endemik. Serum akut diperoleh dari 164 penderita dengan hasil kultur darah positif demam tifoid, dan dilakukan pemeriksaan kadar antibodi anti-LPS (total imunoglobulin, IgA, IgG dan IgM), anti-flagela (total Ig, IgG) dan anti-Vi (total $\mathrm{Ig}, \mathrm{IgG}$ ) dalam serum. Variasi antar individu sangat tinggi pada semua kombinasi antigen-antibodi yang diperiksa. Analisis korelasi menunjukkan bahwa hal ini antara lain disebabkan oleh perbedaan umur dan lama demam. Beberapa penderita, khususnya anak-anak, mempunyai tingkat antibodi yang relatif rendah meskipun telah lama sakit. Hasil penelitian kami menunjukkan bahwa uji diagnosis secara serologis dengan antigen yang digunakan pada penelitian ini mungkin memiliki keterbatasan dalam sensitivitas, khususnya pada anak-anak kecil, pada penderita yang belum lama sakit, dan pada orang-orang yang tinggal di daerah endemis.
\end{abstract}

\begin{abstract}
The aim of this study was to describe the antibody response to Salmonella typhi (S. typhi) antigens (lipolysaccharide (LPS), flagella, $V i)$ in patients with non-severe typhoid fever from an endemic region. Acute serum samples were obtained from 164 patients with blood culture proven typhoid fever. Serum levels of anti-LPS (total Immunoglobulin (Ig), IgA, IgG, IgM), anti-flagella (total Ig, IgG) and anti-Vi (total $\mathrm{Ig}, \mathrm{IgG}$ ) antibodies were determined. Inter-individual variation was high for all antibody-antigen combinations investigated. Correlation analyses showed this was due, in part, to differences in age and duration of fever. Some patients had relatively low antibody levels despite a long history of illness, particularly children. Our results suggest that serological diagnostic tests based on the antigens used in this study may have limited sensitivity, particularly in young children, in patient with a short history of illness, and in those living in endemic areas.
\end{abstract}

\section{INTRODUCTION}

Exposure to $S$. typhi can induce a protective immune response, however, this immunity can break down and second infections can occur, particularly if the rechalenge dose is high ${ }^{1,2}$. The protective components of the immune response are not well defined, but are thought to include both cellular and humoral responses ${ }^{3-8}$. The aim of this study was to describe the total immunoglobulin and class-specific antibody responses to the $S$. typhi antigens LPS, flagella, and Vi.

\footnotetext{
${ }^{I}$ The University of Oxford-Wellcome Trust Clinical Research Unit, Centre for Tropical Diseases, Ho Chi Minh City, Vietnam;

${ }^{2}$ Imperial College of Science, Technology and Medicine, London, UK;

${ }^{3}$ Centre for Tropical Diseases, Ho Chi Minh City, Vietnam;

${ }^{4}$ Department of Infectious Diseases, Faculty of Medicine, University of Medicine and Pharmacy, Ho Chi Minh City, Vietnam
}

\section{MATERIALS AND METHODS}

The study was performed at the Centre for Tropical Disease, a 500 bed infectious diseases hospital in HCMC Vietnam. Patients are referred from the city and the surrounding provinces, including those of the Mekong Delta. Antibodies againts S. typhi LPS, flagella and Vi were measured in serum samples from 164 Vietnamese patients with bacteriologically confirmed non-severe typhoid fever. Ethical permission was obtained from the hospital and informed consent from the patients or guardians.

LPS was purified from BRD985, a Vi negative an $o m p \mathrm{R}$ mutant of BRD691 (a gift from Medeva). Flagella were purified from BRD691, an aroC aroD mutant of Ty2 (kind gift of Medeva). Tyramine-Vi antigen was a kind gift from M.M. Levine.

Standard ELISA protocols were used to detect serum antibodies to LPS, flagella and Vi antigen. Bound immunoglobulin was detected by alkaline phosphatase conjugated detecting antibody and levels interpolated from the standard curve and expressed in arbitrary 
units (i.e. the reciprocal of the - $\log 10$ of the corresponding standard dilution). Spearmens' correlation co-efficients were used to determine the associations between antibody levels, age and duration of illness.

\section{RESULTS AND DISCUSSION}

The median (IQR, range) age of the patients in the study was $18(11-26,1-63)$ years and the median (IQR, range) duration of illnes was 12 (9-17, 3-33) days. There was no correlation between age and duration of illness $(r=0.05, p>0.05)$.

Anti-flagella and anti-Vi total immunoglobulin were found to increase with age $(r=0.36, p<0.001$ and $r=$ $0.17, p=0.03$, respectively) but there was no correlation between anti-LPS total immunolobulin and age $(\mathrm{r}=0.04, \mathrm{p}>0.05)$.

We were able to detect IgG against all three antigens but were unable to detect IgA and IgM to flagella or Vi. Anti-LPS IgM antibodies were found to decrease with age $(r=-0.36, p<0.001)$ while anti-LPS IgG was found to increase with age $(\mathrm{r}=0.17, \mathrm{p}=0.03)$. There was no correclation between $\operatorname{IgA}$ and age $(r=0.04$, $\mathrm{p}>0.05$ ).

Anti-flagella IgG was found to increase with age ( $\mathrm{r}$ $=0.42 . \mathrm{p}<0.001$ ) but there was no correlation between anti-Vi IgG and age, however, IgG levels were only determined in adults ( $>14$ years) for $\mathrm{Vi}$ antigen.

The results are similar to those from healthy individuals from a typhoid endemic area where anti-LPS agglutinating antibodies, presumably IgM and IgG, were detected in sera of subjects of all ages whereas there was an age related increase in anti-flagella antibodies 9 . The switch in the type of anti-LPS response and the increase in flagella and $\mathrm{Vi}$ antibody response suggests that there is an acquisition of some immunity with age.

Significant correlations were found between duration of illness and anti-LPS total immunoglobulin and $\operatorname{IgG}(r=0.24, p=0.002)$, anti-flagella total immunoglobulin and $\operatorname{IgG}(r=0.25, p=0.001)$, and anti-Vi total immunoglobulin and $\operatorname{IgG}(r=0.35, \mathrm{p}<0.001$ and $r=0.31, p=0.002$, respectively). When the data were plotted by week of illness, we found total immunoglobulin , for all three antigens, to peak after the third week of illness.
There was no significant correlation between antiLPS $\operatorname{IgM}$ or $\operatorname{IgA}$ and duration of illness $(\mathrm{r}=0.05$ and 0.1 , respectively, $\mathrm{p}>0.05$ ). it is likely that IgM levels are raised before patients are admitted to hospital and that no further increase is observed. Serum IgA may not be a good indicator of the IgA response which is predominantly found at mucosal sites.

Many patients had relatively low antibody levels despite a long duration of illness. Indeed, the high-interindividual variation and lack of response in some patients suggest that serological tests based on these antigens will have limited sensitivity. Test to detect anti-flagella or anti-Vi antibodies will have geater sensitivity in adults than children, and be of greater use later in the disease than early. Anti-LPS antibodies may be of more use than anti-flagella or anti-Vi antibodies for the diagnosis of typhoid fever.

\section{REFERENCES}

1. Hornick RB, Greisman SE, Woodward TE, DuPont HI, Dawkins AT, Snyder MJ. Typhoid fever: pathogenesis and immunologic control (secound of two parts). New Eng J Med 1970; 283: 739-46.

2. Marmion DE, Naylor GRE, Stewart IO. Second attacks of typhoid fever. J Hyg Camb 1953; 51: 260-7.

3. Hormaeche C, Villarreal B, Mastroeni P, Dougan G, Chatfield SN. Immunity mechanisms in experimental salmonellosis. In: F. Cabello, C.F. Hormaeche, L. Bonina, P. Mastroeni (eds). Biology of Salmonella NATO ASI Aeries A 245. New York: Plenum Press 1992; 323-32.

4. Viret JF, Cryz SJ. Protective immunity induced by typhoid fever and vaccination. Second Asia-Pacific Symposium on Typhoid Fever and other Salmonellosis. 1995; 26: 150-9.

5. Levine MM, Ferreccio C, Black RE, Tacket CO, Germainer $\mathrm{R}$, Chilean Typhoid Committee. Progress in vaccines against typhoid fever. Rev Infec Dis 1989; 11 (suppl 3): S552-67.

6. Blanden RV, Mackaness GB, Collins FM. Mechanisms of acquied resistance in mouse typhoid. J Exp Med 1966; 124: $585-600$.

7. Collins FM, Mackaness GB, Blanden RV. Infection-immunity in experimental salmonellosis. J Exp Med 1966; 124: 601-19.

8. Mastroeni P, Villarreal-Ramos B, Hormarche CE. Adoptive transfer of immunity to oral challenge with virulent Salmonellae in innately suspectible BALB/c mice requires both immune serum and T clls. Infect ImmunI 1993; 61: 3981-4.

9. Levine MM, Grados O, Gilman, RH, Woodward, WE, SolisPlaza R, Waldman R. Diagnostic Value of the Widal test areas endemic for typhoid fever. Am J Trop Med Hyg 1927: 795. 